\title{
ENTRE CERVEJAS, DANÇAS E SANGUE: CRIME E SOCIABILIDADE ENTRE POLICIAIS E POPULARES NA PORTO ALEGRE DE 1889
}

\author{
BETWEEN BEERS, DANCES AND BLOOD: CRIME AND SOCIABILITY \\ BETWEEN POLICE AND POPULAR CLASSES IN PORTO ALEGRE, 1889
}

Giane Caroline Flores*

\begin{abstract}
Resumo: Este artigo pretende analisar através de um processo criminal, no qual é réu um praça da Força Policial, como as noções relacionadas a autoridade, honra e virilidade influenciavam em episódios de conflitos. Além disso, a partir do crime cometido em uma taberna, serão consideradas, não só a atuação e o papel da polícia em Porto Alegre no final do século XIX, mas também o cotidiano destes policiais, responsáveis pela manutenção da ordem pública, e questões relacionadas a sociabilidade, a embriaguez e a cor dos indivíduos envolvidos no episódio.
\end{abstract}

Palavras-chave: Crime. Polícia. Honra.

\begin{abstract}
This article intends to analyze through a criminal process, in which is defendant a member of the Police Force, as the notions related to authority, honor and virility influenced in episodes of conflicts. In addition, from the crime committed in a tavern, it will be considered not only the performance and the role of the police in Porto Alegre at the end of the nineteenth century, but also the daily life of these police officers, responsible for the maintenance of public order, and related issues between the sociability, drunkenness and color of the individuals involved in the episode.
\end{abstract}

Keywords: Crime. Police. Honor

\footnotetext{
* Mestre em História pela Universidade do Vale do Rio dos Sinos (UNISINOS) e Licenciatura em História pela mesma universidade.
} 
Era uma noite de domingo, 4 de agosto de 1889, mais ou menos entre as 19 e 20 horas, na taberna do português Domingos da Costa, situada na rua Vigário José Inácio, centro de Porto Alegre, quando o praça da Força Policial de nome Justino dos Santos estava ao lado de três ou quatro companheiros da mesma instituição, bebendo cerveja, tocando gaita e dançando na companhia de algumas mulheres ${ }^{1}$. Momentos como este, de diversão e sociabilidade entre os membros da polícia, certamente eram corriqueiros, já que deviam fazer parte do cotidiano destes homens, envolvidos em práticas associadas a sua masculinidade. No entanto, a noite de passatempo destes policiais não teve fim de forma tranquila. Pelo menos não para Justino.

O praça da Força Policial, de 27 anos de idade, foi acusado de, na dita noite, ter ferido gravemente com uma facada no ventre o crioulo Antônio Joaquim de Oliveira Paz, um popular, de profissão calceteiro ${ }^{2}$, solteiro e com 30 anos de idade. A vítima também estava em um momento de sociabilidade e descontração, já que, como alegou, encontrava-se tomando cerveja no balcão da taberna, acompanhado de seu amigo Adão José Maria Lessa, 29 anos, casado e pedreiro. Tal atrito, ocorrido na casa de comércio do português Domingos, deu origem a um processo-crime número 1604 encetado pela Justiça Pública contra o réu Justino dos Santos.

A Força Policial, da qual Justino e seus parceiros de festa faziam parte, originou-se a partir do Corpo Policial, instituído em 1837. Cláudia Mauch (2011, p. 38) destaca que em 1873 houve uma reestruturação desta instituição, que não só teve seus efetivos aumentados, como ganhou um novo regulamento e passou a se chamar Força Policial, permanecendo assim até o final de 1889 quando se tornou Guarda Cívica e, posteriormente, em 1892, a Brigada Militar.

É importante destacar que é no final do século XIX que a polícia passa a ganhar importância como um mecanismo de controle social urbano. Isso se dá não só devido a instauração da República, que tinha como um de seus principais pilares a manutenção da ordem e da tranquilidade pública (muito devido aos preceitos positivistas que pautavam o pensamento republicano), mas também devido ao crescimento populacional de cidades como Porto Alegre e a transição da mão-de-obra escravizada para a livre. Circulavam neste período diversos

\footnotetext{
${ }^{1}$ A taberna de Domingos da Costa, durante o decorrer do processo, é chamada pelas testemunhas, réu e vítima por diferentes nomes: taberna, venda, casa de negócios e casa de secos e molhados. Ao longo do inquérito e do julgamento não há mais nenhuma informação a respeito das mulheres que acompanhavam os policiais. Processocrime, Tribunal do Júri de Porto Alegre, no 1694, maço 68, 14 de agosto de 1889, APERS.

${ }^{2}$ Calceteiro é como são designados os operários que trabalham no calçamento de ruas e calçadas - "o que calça a rua com pedras". Em: CONSTÂNCIO, Francisco Solano. Novo Diccionario Critico e Etymologico da LinguaPortugueza. Paris, Tipografia de Casimir / editor Ângelo Francisco Carneiro, 1836, p. 206.
} 
pensamentos de ordem racista, como por exemplo, o da chamada antropologia criminal, formulada pelo antropólogo higienista italiano Cesare Lombroso, que "argumentava ser a criminalidade um fenômeno físico e hereditário e, como tal, um elemento objetivamente detectável nas diferentes sociedades" (SCHWARCZ, 1993, p. 65). Tais pensamentos geravam um receio por parte de governantes e elites que viam na população negra, agora livre, um grupo a ser controlado. Desta forma, como destaca André Rosemberg (2008, p. 17), as instituições policiais tornam-se a opção mais adequada para manter sob controle a população negra:

Era a polícia o mediador mais destacado para impor a nova ordem aos trabalhadores recém-desgarrados das peias da escravidão. Ao garantir a ordem social e a tranquilidade pública, a instituição asseguraria que cada indivíduo se mantivesse no lugar social que a ele estava atribuído no plano das aspirações dos poderosos.

A partir disso, é com a instauração da República que as autoridades passam a tentar, de forma mais enérgica, organizar as forças policiais. Mauch (2011, p. 50) salienta que "as autoridades republicanas idealizaram uma polícia 'civilizada' para Porto Alegre, que conseguisse manter a ordem e a moralidade sem o recurso sistemático à truculência". Apesar de idealizar uma polícia civilizada, disciplinada e bem preparada, colocar isso em prática era bastante difícil para os governantes, e, por muitas vezes, a imagem que se tinha da polícia era a de uma instituição indisciplinada, composta por policiais despreparados, desordeiros e bastante truculentos em suas abordagens. Reclamações sobre esta conduta da polícia eram bastante frequentes nos periódicos locais. Segundo Mauch (2004, p. 153), jornais como o Gazetinha e Gazeta da Tarde, além de considerar ineficiente e insuficiente o policiamento na capital, costumavam culpar pelos problemas de insegurança da cidade os "próprios guardas, que não cumpriam com suas obrigações, envolviam-se em algazarras e dormiam na saleira das portas enquanto os gatunos andavam à solta pela cidade". Para o advogado e diretor da Gazeta da Tarde, Germano Hasslocher, em 1895, o policiamento da cidade era ineficiente e feito por policiais desqualificados:

O policiamento das ruas da cidade não valia nada porque, ao contrário do pessoal superior da administração da polícia, os quadros eram na sua totalidade 'soldados boçais', analfabetos e sem noção do dever. 'Não temos o 
policial verdadeiro' - reclamava, e sim 'pobres diabos' incapazes de merecer a confiança das autoridades. (MAUCH, 2004, p. 155).

Esta visão negativa sobre o policiamento se dava não só pela falta de treinamento adequado e de investimentos, mas principalmente devido ao comportamento dos policiais que além de constantemente serem encontrados em estado de embriaguez durante o trabalho, agredirem de forma arbitrária populares, também envolviam-se frequentemente em brigas e confrontos. Estas brigas geralmente estavam associadas a um constante processo de construção e afirmação de masculinidade e autoridade destes policiais. Mauch $(2011$, p. 30) ao tratar do processo de institucionalização da polícia, destaca que a autoridade destes homens populares fardados necessitava ser afirmada e reconhecida diariamente:

Tal autoridade, em princípio, já se fazia presente no ato legal que inaugurou a polícia, mas precisou ser afirmada e reconhecida diariamente, de muitas formas, em seu contato com a população, com as outras instituições sociais e estatais, com poderes que se manifestavam por meio de diferentes atores sociais, individuais e coletivos. [...] essa autoridade era constantemente reinventada e seus sentidos atualizados contextualmente, no âmbito das interações sociais; sendo a autoridade, assim entendida, o que podia dar fundamento a uma identidade entre os policiais no período.

Além da construção da autoridade, a defesa da honra também se fazia presente no cotidiano dos policiais de fins do século XIX. As concepções de virilidade e masculinidade estavam intrinsicamente ligadas às brigas, rivalidades e confrontos que ocorriam pelas ruas, durante as rondas e também durante os momentos de sociabilidade destes indivíduos. Manter a honra masculina era essencial para estes homens fardados que não hesitavam em sacar suas facas e cassetetes para agredir a quem estivesse colocando esta honra em cheque. Beattie (2009, p. 272) destaca que estas concepções de honra masculina enfraqueciam as tentativas de disciplinar os corpos militares e policiais, já que em diversos momentos resultavam em confrontos prejudiciais a esta disciplina:

A virilidade é testada e sua competência exibida em público, caso contrário, um homem pode ser ridicularizado em termos de gênero. Tal prova, às vezes, se dá em detrimento da honra de um companheiro, encorajando confrontos prejudiciais à disciplina militar. Obviamente, alguns indivíduos estão menos preocupados com as opiniões e gracejos de seus pares, e percepções da conduta masculina adequada variam de acordo com as circunstancias, regiões, 
grupos e indivíduos. Contudo, os homens sempre percebem ou racionalizam suas condutas em termos de uma linguagem de honra amplamente compartilhada.

No que tange ao Rio Grande do Sul, ao analisar a honra através dos escritos de Caldre e Fião, José Remedi (2011, p.166) destaca o "tipo heroico sul-rio-grandense", um sujeito com “altos padrões de honorabilidade". Muito deste caráter de homem heroico e honrado que pairava sobre o gaúcho, provinha da participação nas guerras em que a Província, depois Estado, se envolveu, como a Farroupilha, a Guerra do Paraguai e a Federalista que ocorreu no período estudado de investimentos na polícia. Para além das questões de honra, das provações do "ser homem", as participações nestes conflitos também poderiam ser encarados por muitos homens fardados como um momento de afirmação de virilidade. A prática da degola, por exemplo, utilizada em larga escala durante a Revolução Federalista (1893-1895), que contou com a participação de praças da Brigada Militar e da Guarda Municipal, pode ser vista como uma forma de demonstração de força viril ${ }^{3}$.

Retornando a briga de bar do praça da Força Policial, Justino dos Santos, que deu origem a este artigo, o conflito certamente teve como base estas questões relacionadas a honra, autoridade e masculinidade. Para esclarecer os acontecimentos, foram chamados como testemunhas no processo o português Domingos, dono da casa de secos e molhados; Adão, amigo da vítima; e os praças da Força Policial que encontravam-se no local: Alexandre José Bernardo, João Lopes Benfica e Manoel Antônio da Rosa.

No depoimento da vítima, ao ser inquirido pelo subdelegado Nicolau Birnfeld sobre o fato, disse que, enquanto tomava cerveja no balcão da venda com seu companheiro Adão, o réu saiu do interior do estabelecimento, de um quarto onde estava com outros praças da polícia, e dirigiu-se até ele fazendo-lhe, sem motivo algum, o ferimento no ventre com a faca que trazia consigo. Após isso, teria o policial retornado a companhia de seus colegas.

\footnotetext{
${ }^{3}$ A prática da degola era praticada pelos inimigos dos policiais recrutados para a campanha. Foi devido ás práticas da Revolução Federalista que surgiu a expressão popular “não se gasta pólvora com chimango!”. Pesavento (1983, p. 90) ressalta que chimango foi a alcunha que os republicanos receberam durante o governo de Borges de Medeiros e, na concepção dos maragatos (federalistas, liderados por estancieiros da Campanha e antigos membros da Guarda Nacional), não valia a pena gastar tiros para acabar com os inimigos republicanos, utilizavam a faca que era um método mais simples e barato.
} 
O pedreiro Adão, amigo da vítima e primeira testemunha inquirida no processo, corrobora com o depoimento do ofendido, acrescentando ainda que notou que Justino estava embriagado e que momentos antes da agressão gratuita do policial contra Antônio Joaquim, os três juntos "tomaram cerveja, sem que nessa ocasião houvesse entre um e outro a menor questão ou troca de palavras", por esse motivo, acredita que entre o ofensor e o ofendido não havia nenhuma rixa ou desavença ${ }^{4}$.

Pode-se notar que os populares paisanos procuram classificar, através de seus depoimentos, a atitude do réu como injustificada, dando a entender que foi uma agressão gratuita, sem motivo algum, podendo ter sido, inclusive, impulsionada pelo estado de embriaguez do policial. Como foi comentado, não eram raras as críticas à atuação policial encontradas nos jornais locais. Denúncias de arbitrariedades cometidas por policiais também eram comuns nos periódicos, onde apareciam de forma recorrente críticas as agressões gratuitas de policiais que utilizavam de sua autoridade e cometiam abuso de poder contra populares ${ }^{5}$. É possível que a vítima e seu amigo estivessem tentando convencer as autoridades de que o fato em questão foi um destes casos.

A segunda testemunha inquirida foi o português Domingos, de 39 anos, casado e, além de dono da venda, ferreiro. O taberneiro acrescentou uma nova informação à investigação. Segundo ele, o ofendido Antônio Manoel saiu do quarto em que estavam "diversas pessoas, entre elas três ou quatro praças de polícia”, tocando gaita e dançando, e dirigiu-se a ele, dizendo que o praça Justino não havia consentido que ele, vítima, dançasse. Como Antônio dirigiu-se ao balcão e o policial permaneceu no quarto, ele testemunha não se preocupou em "apaziguálos". Contudo, relatou que "um crioulo que foi praça de polícia, cujo nome ignora, foi dizer a Justino que o ofendido estava ali falando mal dele e foi isto o bastante para que Justino viesse

\footnotetext{
${ }^{4}$ Processo-crime, Tribunal do Júri de Porto Alegre, no 1694, maço 68, 14 de agosto de 1889, APERS, folhas 10 a 11.

${ }^{5}$ Um exemplo destas arbitrariedades policiais encontra-se na edição de 03 de fevereiro de 1886 do jornal $A$ Federação. Ao falar do policiamento na Festa dos Navegantes, os redatores do jornal destacam que tudo ocorria com ordem e regularidade até que "A policia também exhibio-se com a costumada...desordem", isto pois "entrou um pobre homem, de cor, que conversava com um camarada, em um dos botequins do arraial. A policiaprohibio a palestra, e, sem mais nem menos, foi esbordoando o infeliz, fazendo-lhe o sabre um profundo golpe na cabeça." Fonte: A Federação, n. 27, 03 de fevereiro de 1886, p. 1.
} 
do interior da casa e ferisse ao ofendido", ocorrendo após "disputa entre os dois". Disse ainda que ambos encontravam-se bastante embriagados ${ }^{6}$.

Sempre lembrando que os depoimentos das testemunhas muitas vezes podem trazer versões distorcidas - ou até mesmo falsas - da realidade dos fatos, as informações trazidas ao processo por Domingos podem suscitar algumas ideias do que poderia ter iniciado o conflito na taberna. Primeiramente chama a atenção no relato do taberneiro que ele foi procurado pela vítima que queixava-se de ser impedido por Justino de participar da confraternização e da dança que ocorria entre os praças da Força Policial. Uma hipótese que pode ser levantada a partir disso é a de que estes policiais não queriam "misturar-se" com populares em determinadas ocasiões. Mesmo que estes agentes da segurança pública tivessem soldos baixíssimos ${ }^{7}$ e vivessem em condições tão difíceis quanto as dos demais populares da cidade, a farda, símbolo de autoridade, lhes conferia um certo prestígio e distinção social, que eles, neste momento, não gostariam de compartilhar.

Além disso, Domingos relata que "um crioulo que foi praça de polícia" disse a Justino que o ofendido estava falando mal dele. Ora, não é de estranhar que questões como essa gerassem desentendimentos. Isto porque a masculinidade, guiada por ideais de honra e virilidade, era afirmada de forma ainda mais evidente entre membros de instituições policiais. Mauch (2008, p. 3) ressalta que "na maioria das descrições de conflitos envolvendo policiais e não-policiais, a afirmação da autoridade e a disputa de masculinidade se confundiam ou se sobrepunham”. A autora ainda destaca que nos casos de provocações destinadas aos membros da polícia, "a medida do 'ser homem' passa pela demonstração de coragem e força física", sendo assim, ao ser provocado ou atacado "se o policial 'for homem' deverá responder à altura" (MAUCH, 2008, p. 4-5).

${ }^{6}$ Processo-crime, Tribunal do Júri de Porto Alegre, no 1694, maço 68, 14 de agosto de 1889, APERS, folhas 11 a 12.

${ }^{7}$ Conforme o quadro de vencimentos da Guarda Cívica, em 1889 o ordenado de um soldado era de $192 \$ 000$, enquanto os cabos recebiam 228\$000. De acordo com Cláudia Mauch (2011, p. 130) em 1896, por exemplo, os agentes suburbanos da polícia administrativa de Porto Alegre tinham vencimentos de 1:080\$000 (o que corresponderia a um salário mensal de $200 \$ 000)^{7}$. Essa situação parecia ser um fator comum aos policiais de todo o país. Cristiana Schettini Pereira (2002, p. 47), ao analisar as relações entre policiais e meretrizes no Rio de Janeiro nas primeiras décadas da República, comenta que praças e guardas civis que se relacionavam com estas mulheres, muitas vezes, contavam com o apoio financeiro delas já que, segundo a autora, não era raro que as "meretrizes" tivessem renda maior que a dos policiais. 
Nesse sentido, é bastante plausível que Justino tivesse se sentido ofendido e com sua honra e autoridade questionadas ao saber que um popular "qualquer" falava mal dele, partindo para o "acerto de contas" através da facada proferida contra Antônio Joaquim. Além disso, é importante destacar que, além de não ser policial, a vítima era negra, sendo registrada na Santa Casa de Misericórdia, no dia da agressão, como preto $^{8}$. Pensando nisso, seria possível que pesasse ainda mais no sentimento de "desonra" do policial, o fato da vítima ser um homem negro. No entanto, Justino, mesmo que isto não apareça nos autos do processo, não era branco. Em quatro entradas do policial na Santa Casa de Misericórdia, entre agosto de 1888 e junho de 1889, ele foi registrado como $p a r d o^{9}$, o que pode ter influenciado no resultado de seu julgamento, como será visto adiante ${ }^{10}$.

Um último ponto que ainda deve ser considerado sobre o depoimento de Domingos é o estado de embriaguez dos envolvidos no conflito. O uso exagerado de bebida alcóolica, motivo de muitas das prisões correcionais no período, podia levar seus usuários a agressão física e a violência devido a qualquer troca de palavras rudes ou atos considerados desrespeitosos. Daisy de Camargo (2010, p. 151), ao tratar da cidade de São Paulo no final do século XIX e início do $\mathrm{XX}$, comenta que são inúmeros os processos criminais em que os envolvidos encontravam-se em estado de embriaguez: "Em vários processos réus são acusados de, impulsionados pela bebedice, provocar a perturbação do sossego público".

\footnotetext{
${ }^{8}$ A referência a cor de Antônio Joaquim aparece apenas uma vez no processo criminal, no depoimento da testemunha João Lopes Benfica, praça da Força Policial, que disse saber do acontecido pelo réu, que contou-lhe que tinha sido acusado como autor "de ferimentos feitos em um crioulo". Processo-crime, Tribunal do Júri de Porto Alegre, no 1694, maço 68, 14 de agosto de 1889, APERS, folha 27. Quanto a entrada da vítima na Santa Casa, constam em seu registro de número 716 do dia 05 de agosto de 1889, as seguintes informações: Antônio Joaquim d'Oliveira Paz, 30 anos, natural desta Província, cor preta, filho de outro de mesmo nome, profissão calceteiro, solteiro, pobre, com ferimento por arma branca no baixo ventre, teve alta por estar curado em 23 de agosto do mesmo ano. Livro 6 de Matrícula Geral dos Enfermos da Santa Casa de Misericórdia, folha 31.

${ }^{9}$ Justino dos Santos deu entrada como paciente da Santa Casa nas seguintes datas: 06 de agosto de 1888, com alta em 17 do mesmo mês, por um abcesso; em 17 de outubro de 1888, com alta dois dias depois, com amidalite; em 03 de maio de 1889, com alta em 07 do mesmo mês, devido a uma laringite; e em 14 de junho de 1889, tendo alta três dias depois, devido a uma contusão. Nas 4 diferentes internações ele é registrado como natural desta Província, pardo, pais incógnitos, solteiro, classe Polícia, profissão ferreiro. Livro 6 de Matrícula Geral dos Enfermos da Santa Casa de Misericórdia, folhas 3, 8, 25 e 28.

${ }^{10}$ Cabe destacar um detalhe sobre o processo, conforme o depoimento do taberneiro Domingos quem "dedurou" a Justino que estavam falando mal dele foi "um crioulo que foi praça de polícia", nesse sentido é interessante notar que um ex-policial ainda compartilhava afinidades com seus ex-colegas de farda, frequentando os mesmos ambientes do que eles, trocando conversas e, como neste caso, procurando "defender a honra" de seus companheiros.
} 
A autora destaca ainda o papel da medicina e dos higienistas no que toca ao "mal da embriaguez", tão presente entre os populares. Segundo ela, no decorrer do século XIX os médicos que, ao lado do Estado, procuravam controlar a população pobre e os problemas de saúde pública, passaram a adotar uma política de combate a determinados hábitos e vícios considerados impróprios. Dentro disso encontrava-se o que a autora chama de "pedagogia antialcoólica":

Essa pedagogia antialcoólica faz parte de um novo projeto de domesticação das classes menos favorecidas [...]. As bebidas espirituosas, o fumo, os exageros, são sistematicamente reprimidos. O álcool é visto mais uma vez como elemento de degradação física e moral. (CAMARGO, 2010, p. 185).

Nesse sentido, ainda segundo Camargo (2010, p. 184), procurava-se atribuir ao consumo do álcool uma série de consequências negativas como a "violência, a perda da vergonha, o crime, a cadeia, a miséria, a loucura". Estas ideias sobre a embriaguez, que circulavam nos periódicos locais, podiam ser utilizadas em casos como o de Justino, para justificar o crime cometido, o que ele mesmo alega durante seu interrogatório. Ao ser perguntado pelo juiz se tinha fatos a alegar ou provas que justificassem ou mostrassem sua inocência, Justino dos Santos:

Respondeu que sim. Baseia-se esta de não ter consciência o acusado do mal que praticou. Que não sendo ele dado ao vício da embriaguez, devido a fatalidade na noite em que se deu o delicto tomando parte ele acusado na reunião que dava em sua casa Domingos Costa, por ser dia de São Domingos, excedeu-se na bebida e perdeu a consciência de si. Não pode duvidar que fosse ele acusado quem ferio a Antonio Joaquim de Oliveira Paz, isto porque algumas pessoas lhe dizem, inclusive o dito Domingos Costa pessoa que lhe merece fé, mas como cometeu o crime e de que faca serviu-se não se lembra e ele próprio admira-se disso pois não trazia consigo faca alguma. $E$ tanto isto é certo que proposital ou premeditadamente fez o ferimento em um dos convívios daquela noite com o qual, se não mantinha estreitas relações de amizade, não tinha contra ele indisposição alguma. ${ }^{11}$

A alegação do réu, em sua defesa, trata então de justificar seu ato pelo consumo da bebida alcóolica, que o teria feito perder a consciência. Ele ainda faz questão de destacar que

\footnotetext{
${ }^{11}$ Processo-crime, Tribunal do Júri de Porto Alegre, $n^{\circ}$ 1694, maço 68, 14 de agosto de 1889, APERS, folhas 34 a 35. Optou-se por manter a grafia original da fonte. Grifo meu.
} 
não é dado ao vício da embriaguez, e que o consumo de cerveja na noite do crime foi uma fatalidade. Cabe destacar que Justino dos Santos era praça da Força Policial há quase dois anos, como destaca em seu interrogatório, e que por isso era bastante conhecido por seus colegas e superiores, algo dito pelos demais praças que estavam presentes na taberna na noite do crime. Como aponta Cláudia Mauch (2011, p. 131), havia uma grande rotatividade de agentes na polícia, muitos dos indivíduos que se engajavam permaneciam por pouquíssimo tempo na instituição, enquanto outros saíam e voltavam algum tempo depois. O fato de Justino ser praça a dois anos ininterruptos, como ele alega, poderia ser bastante tempo em comparação com a maioria de seus demais colegas, fato que contribuiria para o estabelecimento de vínculos e relações de proximidade do praça por seus superiores e parceiros.

O primeiro policial a testemunhar foi Alexandre José Bernardo, com 22 anos, solteiro, sabia ler e escrever. Disse que estava se divertindo na venda de Domingos em companhia do acusado e de outros praças, e que apenas lembra do réu retirar-se para o quartel. Ele testemunha apenas teve conhecimento do fato quando também dirigiu-se ao quartel e verificou a prisão de Justino. Questionado sobre a conduta do acusado, respondeu que "nada podia dizer em desabono do acusado como praça e como particular e pelo contrário pode afiançar que ele goza da estima de seus superiores e companheiros" ${ }^{12}$.

Em seguida quem depôs foi o praça da Força Policial João Lopes Benfica, de 22 anos de idade, solteiro, desta província, que não sabia ler nem escrever. Disse que estando em um quarto na venda do português Domingos, na noite do dia 4 de agosto, não viu e nem soube do crime, e somente ficou sabendo do fato no dia seguinte, quando viu o réu no xadrez. Ao ser questionado sobre a conduta do acusado, "respondeu que o conhece e sabe ser este morigerado, pacato, sem vicio de embriaguez e estimado dos seus superiores e por assim conhece-lo que admirou-se de vê-lo alcoolizado naquela noite"13.

O último policial a testemunhar é Manoel Antônio da Rosa, 22 anos de idade, solteiro, não sabe ler e nem escrever. Testemunhou que divertia-se com seus companheiros quando o acusado entrou no recinto, mas ele não prestou "grande atenção em sua permanência ali",

\footnotetext{
${ }^{12}$ Processo-crime, Tribunal do Júri de Porto Alegre, $\mathrm{n}^{\circ}$ 1694, maço 68, 14 de agosto de 1889, APERS, folhas 25 a 26.

${ }^{13}$ Processo-crime, Tribunal do Júri de Porto Alegre, $n^{\circ}$ 1694, maço 68, 14 de agosto de 1889, APERS, folhas 27 a 28.
} 
"lembra-se entretanto que não foi longa" e que soube do fato apenas por ouvir dizer, já que não ouviu barulho algum. Ao ser perguntado sobre a conduta de Justino:

Respondeu que o conhece há muito tempo mesmo antes de ser seu companheiro como praça e não lhe consta ser desordeiro, dado ao vício da embriaguez e de péssimos costumes e como praça seu comportamento é tão bom que é estimado de seus superiores, pelo que tem causado admiração nem só a embriaguez dessa noite como o facto que lhe é imputado. ${ }^{14}$

Através dos depoimentos prestados pelos três policiais, é possível notar que eles pretendem eximir-se como testemunhas oculares do fato criminoso cometido por seu colega, dizendo que não presenciaram, nem viram ou ouviram o conflito. É bastante difícil que a briga que resultou em uma facada no ventre de Antônio não gerasse confusão e barulho no recinto e que, mesmo com música, seria ouvida pelos presentes. Possivelmente estes praças tentaram proteger seu companheiro ao não contarem o que ocorreu naquela noite. Além disso, merece destaque o fato de que todos os três ressaltam a boa conduta de Justino, dizendo ser ele um sujeito pacato, morigerado e que a embriaguez na noite do crime foi algo fora do habitual. Além do depoimento favorável de seus companheiros, Justino também contou com um atestado anexado ao processo no qual o Comandante da Força Policial declara que durante o tempo em que esteve sob seu comando o praça apresentou comportamento regular na instituição ${ }^{15}$.

Como já foi comentado, apesar dos membros das forças de polícia serem oriundos das classes populares e receberem baixos salários, esses sujeitos contavam com alguns benefícios enquanto policiais. Mesmo que não possuíssem bens materiais e financeiros, estes sujeitos contavam com um capital social possibilitado pela farda. No processo movido pela justiça contra Justino dos Santos, é possível ver que ele foi protegido e teve sua imagem bem descrita e avaliada por seus companheiros da Força Policial, o que pode ter pesado a seu favor no julgamento.

A promotoria, durante o julgamento, pedia a incursão do réu nas penas do artigo 205 do Código Criminal, que previa de um a oito anos de prisão com trabalho para ofensas físicas que produzissem grave incômodo de saúde ou inabilitação do serviço por mais de um mês. O júri

\footnotetext{
${ }^{14}$ Processo-crime, Tribunal do Júri de Porto Alegre, no 1694, maço 68, 14 de agosto de 1889, APERS, folhas 28 a 29.

${ }^{15}$ Processo-crime, Tribunal do Júri de Porto Alegre, no 1694, maço 68, 14 de agosto de 1889, APERS, folha 59.
} 
popular, reunido em 9 de setembro de 1889, considerou Justino culpado, porém ele foi implicado no artigo 201, que punia por ferimentos ou ofensas físicas e que previa prisão de um mês a um ano ${ }^{16}$. Como o réu encontrava-se preso desde a data do crime, em 4 de agosto o juiz considerou que o tempo de reclusão, que foi de um pouco mais de um mês, era o suficiente e mandou expedir mandato de soltura ao praça.

O júri considerou que a facada feita por Justino em Antônio Joaquim não provocou grave incômodo a vítima e nem lhe inabilitou por mais de um mês do trabalho, uma vez que segundo atestado do médico que lhe tratou na Santa Casa e que foi anexado ao processo - o ferido recebeu alta menos de 20 dias após o ocorrido. Mesmo que não seja explicitado nos quesitos respondidos pelos jurados, possivelmente alguns "atenuantes" foram considerados em favor do réu. Entre eles, a própria posição do mesmo como praça da Força Policial há mais de dois anos, os elogios proferidos por seus colegas de profissão, o atestado de boa conduta policial redigido pelo comandante, o estado de embriaguez do policial - afirmado como um caso isolado - e também da vítima, e por fim, a cor do ofendido.

Ribeiro (1995), ao estudar a justiça no Rio de Janeiro no início do século XX, procura observar em que medida pesavam nas decisões do Tribunal do Júri as representações sociais da cor das vítimas e réus envolvidos em processos criminais. A partir disto, o autor chegou a algumas conclusões. Segundo ele, se o acusado era um sujeito preto ou pardo, a probabilidade de ele ser condenado era muito maior do que a de um indivíduo branco:

A cor preta do acusado aumenta, mais do que qualquer outra característica, a probabilidade de condenação no Tribunal do Júri. [...] O acusado preto tem 31,2 pontos percentuais a mais de probabilidades ou chances de ser condenado do que o acusado branco, e o acusado pardo tem 15,8 pontos percentuais a mais de chances de condenação do que o acusado branco. Obviamente podese observar que o fato de não ser branco era uma agravante que aumentava significativamente as probabilidades de condenação dos acusados submetidos ao Tribunal do Júri. (RIBEIRO, 1995, p. 72-73).

Considerando isso, mesmo que não esteja presente nos autos, o fato de Justino dos Santos ser pardo, pode ter contribuído para que fosse considerado culpado. Talvez um policial

${ }^{16}$ O Artigo 201 do Código Criminal de 1830 referia-se a: "Ferir ou cortar qualquer parte do corpo humano, ou fazer qualquer outra ofensa physica, com que se cause dôr ao ofendido". Código Criminal do Império do Brazil de 16 de dezembro de 1830, Disponível em: < http://www.planalto.gov.br/ccivil_03/leis/lim/lim-16-12-1830.htm>. 
branco na mesma situação tivesse sido absolvido ${ }^{17}$. No entanto, cabe destacar que não só a cor do acusado pesava nas decisões do júri. A cor da vítima, ou do ofendido, também era um fator determinante para a condenação ou absolvição do réu. Segundo Ribeiro (1995, p. 73), ao cometer um crime contra um preto, o acusado teria $14,5 \%$ de chances a menos de ser condenado: "[...] a probabilidade de absolvição para um acusado de ter cometido um 'crime de sangue' contra um preto ou um pardo é maior do que a de um acusado de ter cometido um crime semelhante contra um branco". Nesse sentido, o fato de Antônio Joaquim ser preto, solteiro e estar embriagado - como alegaram as testemunhas -, podem ter sido fatores que também contribuíram para o curto tempo de prisão do acusado.

As fontes consultadas na pesquisa não possibilitam seguir os destinos dos envolvidos no conflito. Sobre a fonte, é importante citar o artigo de Karl Monsma (2011, p.28) que atenta para o fato de que os "processos criminais não necessariamente representam bem a totalidade dos crimes do contexto abordado", necessitando de um processo de seleção adequada par ao manejo deste tipo de fonte. Apesar disso, Maíra Vendrame (2016, p. 31) ressalta que através deste tipo de fonte é possível encontrar interessantes informações sobre episódios e protagonistas locais, além de práticas sociais e ações cotidianas. Nesse sentido, a fatídica briga entre o policial Justino dos Santos e Antônio Joaquim na noite de 4 de agosto de 1889, permite pensar em alguns aspectos do cotidiano e das relações destes trabalhadores do controle social.

Por fim, cabe destacar que não só Justino era um policial de cor, uma das testemunhas, o praça João Lopes Benfica, era preto $^{18}$. Muito provavelmente estes policiais eram frequentadores assíduos da taberna do português Domingos, uma vez que mostram afinidade com o dono da venda, já que para Justino, "Domingos é pessoa que lhe merece fé"19. O local

\footnotetext{
${ }^{17}$ Embora esta seja uma hipótese sem nenhum tipo de provas ou indícios, vale lembrar que não são raros, atualmente, os casos de policiais - especialmente os brancos - que são absolvidos de crimes. Para citar um exemplo, em dezembro de 2017, o policial Levy Moura de Sousa foi absolvido pela morte do estudante de 20 anos Luan Vitor de Oliveira, morto em 2013 durante um show em Goiás. O júri considerou que o policial agiu em legítima defesa. $\mathrm{O}$ crime de assassinato do jovem foi gravado por câmeras de segurança. Esse é apenas um dos inúmeros casos que ocorrem no Brasil. São frequentes os assassinatos de jovens negros em favelas e periferias. Nos Estados Unidos, casos de policiais brancos absolvidos por matarem jovens negros ocorrem frequentemente, mostrando que casos de abuso de poder e racismo andam intimamente ligados.

1802 de fevereiro de 1889, 22 anos, desta Província, cor preta, pais incógnito, solteiro, classe Polícia, com embaraço gástrico, teve alta por estar curado em 04 do mesmo mês. Livro 6 de Matrícula Geral dos Enfermos da Santa Casa de Misericórdia, folha 14. As demais testemunhas do processo não constam nas internações da Santa Casa no período pesquisado e, portanto, não se sabe se tratavam-se de brancos, pardos, morenos ou pretos.

${ }^{19}$ Processo-crime, Tribunal do Júri de Porto Alegre, no 1694, maço 68, 14 de agosto de 1889, APERS, folhas 34 a 35. Optou-se por manter a grafia original da fonte. Grifo meu.
} 
situado no centro da cidade parecia ser não só um local de sociabilidade popular, frequentado por policiais, mas um local onde "homens de cor" reuniam-se para conversar, cantar, dançar e beber. Vale lembrar ainda que a taberna do português Domingos ficava na rua Vigário José Inácio, que recebeu este nome apenas em 1877, sendo antes chamada de Beco e depois Rua do Rosário, justamente por ali estar o principal templo que congregava a religiosidade afro-católica de Porto Alegre ${ }^{20}$. Talvez aqueles homens negros transitassem normalmente do templo à taberna, do religioso ao profano, (re)criando identidades étnicas e afinidades laborais. Ás vezes, em meio a isto, as diferentes relações hierárquicas e as noções de honra, masculinidade e virilidade vinham à tona através de conflitos, disputas e agressões.

\section{Referências bibliográficas}

BEATTIE, Peter M. Tributo de sangue: Exército, Honra, Raça e Nação no Brasil 1864-1945. São Paulo: Editora da USP, 2009.

CAMARGO, Daisy de. Alegrias engarrafadas: os álcoois e a embriaguez na cidade de São Paulo no final do século XIX e começo do XX. 2010. 257 f.Tese (Doutorado em História) Faculdade de Ciências e Letras, Universidade Estadual Paulista Júlio de Mesquita Filho (UNESP), Assis - São Paulo, 2010.

CONSTÂNCIO, Francisco Solano. Novo Diccionario Critico e Etymologico da LinguaPortugueza. Paris, Tipografia de Casimir / editor Ângelo Francisco Carneiro, 1836.

MAUCH, Cláudia. Dizendo-se autoridade: polícia e policiais em Porto Alegre, 1896-1929. Porto Alegre, PPGH/Universidade Federal do Rio Grande do Sul, 2011.

Masculinidade e violência na construção da autoridade de policiais no início do século XX no sul do Brasil. Seminário A Polícia em perspectiva histórica: Argentina e Brasil. Buenos Aires: 2008. Retirado de: <http://www.crimenysociedad.com.ar/wpcontent/uploads/2008/06/mauch.doc>.

. Ordem Pública e moralidade: imprensa e policiamento urbano em Porto Alegre na década de 1890. Santa Cruz do Sul: EDUNISC/ANPUH-RS, 2004.

\footnotetext{
${ }^{20}$ MÜLLER, Liane Susan. As contas do meu rosário são balas de artilharia: irmandade, jornal e associações negras em Porto Alegre (1889-1920).Dissertação de Mestrado. Porto Alegre, PPGH/PUCRS, 1999; TAVARES, Mauro Dillmann. Irmandades, Igrejas e Devoção no Sul do Império do Brasil. São Paulo, UNISINOS/ OIKOS, 2008.
} 
MONSMA, Karl. O problema de viés de seleção na pesquisa histórica com fontes judiciais e policiais. História Sociais. N.21, 2sem, 2011.

PEREIRA, Cristiana Schettini. Que tenhas teu corpo: uma história social da prostituição no Rio de Janeiro das primeiras décadas republicanas. Campinas, Universidade Estadual de Campinas, 2002, Tese (doutorado).

PESAVENTO, Sandra Jatahy. A Revolução Federalista. São Paulo: Brasiliense, 1983.

REMEDI, José Martinho Rodrigues. Palavras de honra: um estudo acerca da honorabilidade na sociedade sul-rio-grandense do século XIX, a partir dos romances de Caldre Fião. São Leopoldo, tese de doutoramento, UNISINOS, 2011.

RIBEIRO, Carlos Antonio Costa. Cor e criminalidade: estudo e análise da justiça no Rio de Janeiro (1900 - 1930). Rio de Janeiro: Editora UFRJ, 1995.

ROSEMBERG, André. Polícia, policiamento e o policial na província de São Paulo, no final do Império: a instituição, prática cotidiana e cultura. São Paulo: USP, 2008 (Tese de doutorado).

SCHWARCZ, Lilia Moritz. $O$ Espetáculo das Raças. Cientistas, instituições e questão racial no Brasil: 1870-1930. São Paulo, Cia. Das Letras, 1993.

VENDRAME, Maíra Ines. O poder na aldeia: redes sociais, honra familiar e práticas de justiça entre os camponeses italianos (Brasil-Itália). São Leopoldo: Oikos; Porto Alegre: ANPUH-RS, 2016. 